\title{
Analisis Hubungan Manajerial Kepala Ruangan dan Faktor-Faktor yang Mempengaruhi Kinerja Perawat dengan Kualitas Dokumentasi Asuhan Keperawatan di Ruang Rawat Inap RSUD Pariaman
}

\author{
Fithri Yani ${ }^{1}$, Fatma Sri Wahyuni ${ }^{2}$, Vetty Priscilla ${ }^{3}$ \\ ${ }^{1}$ Program Studi Magister Keperawatan Kekhususan Manajemen Keperawatan Uiversitas andalas \\ 2Program Studi IImu Farmasi Universitas Andalas \\ ${ }^{3}$ Program Studi Magister Keperawatan Universitas Andalas \\ Correspondence email: fithri.yani25@gmail.com, fithri.yani25@yahoo.co.id
}

\begin{abstract}
Abstrak. Kualitas asuhan keperawatan dapat tergambar dari dokumentasi asuhan keperawatan. Dokumentasi asuhan keperawatan yang tidak dilakukan dengan lengkap dapat menurunkan kualitas pelayanan keperawatan karena tidak dapat mengidentifikasi sejauh mana tingkat keberhasilan asuhan keperawatan yang diberikan. Hal ini menjadi wujud dari kinerja perawat. Perawat dalam menjalankan tugasnya juga dipengaruhi oleh kemampuan fungsi manajerial kepala ruangan yang mempengaruhi kinerja perawat. Penelitian ini bertujuan untuk menganalisis hubungan fungsi manajerial kepala ruangan dan faktor-faktor yang mempengaruhi kinerja perawat dengan kualitas dokumentasi asuhan keperawatan di ruang rawat inap RSUD Pariaman. Desain penelitian analitik deskriptif dengan pendekatan cross sectional. Sampel 86 orang perawat dengan teknik proporsional random sampling. Hasil penelitian menunjukkan fungsi perencanaan, fungsi pengorganisasian, fungsi pengarahan, fungsi pengawasan , fungsi pengendalian sebagian besar baik, umur perawat rata-rata 31,5 tahun, masa kerja rata-rata 4,5 tahun, status kepegawaian sebagian besar PNS dan tingkat pendidikan perawat sebagian besar D3 keperawatan, faktor organisasi (imbalan) baik, faktor psikologis (sikap, motivasi sebagian besar baik). Hasil uji statistik adanya hubungan antara fungsi pengarahan dengan kualitas dokumentasi asuhan keperawatan ( $p$ value $=0,042$ ). Saran bagi Kepala bidang keperawatan untuk melakukan revisi Standar Asuhan Keperawatan sesuai dengan kondisi dan pedoman saat ini, melakukan penilaian kinerja perawat tentang pendokumentasian asuhan keperawatan secara berkala dan menyelenggarakan pelatihan-pelatihan terkait dengan dokumentasi asuhan keperawatan yang sesuai standar yang dibina oleh tenaga ahli dan profesional.
\end{abstract}

Kata kunci: fungsi manajerial; kinerja; kualitas dokumentasi asuhan keperawatan

Abstract. The quality of nursing care can be drawn from the documentation of nursing care. Nursing care documentation incomplete can degrade the quality of nursing services because it can't identify the extent to which the success rate of nursing care given. It becomes of performance of nurses. Nurses in performing their duties are also influenced by the ability of the managerial functions of the head nurse that affects the performance of nurses. This study aimed to analyze the relationship between the head nurse managerial functions and the factors that affect the performance of nurses with documentation quality of nursing care in inpatient Pariaman Hospitals. The Study using analiytical descriptive design with cross sectional approach. Samples were 86 nurses with proportional random technique sampling. The result research showed that planning function, organizing function, directing function, monitoring function, controlling function majority is good, the average age of nurses 31,5 years, the average life of 4,5 years, most of the employment status of civil servants and education level of nurses majority diploma nursing,organizational factors (rewards) majority is good, psychological factors (attitude, motivation majority is good). The statistical test result correlation between the function of directing the quality of nursing care documentation ( $p$ value $=0.042$ ). Suggestions for head of nursing revised Nursing Care Standards, assessing the performance of nurses regarding documentation of nursing care on a regular basis using an assessment instrument and the implementation of training related to nursing care documentation appropriate standard built by experts and professionals.

Keywords: managerial functions; performance; the quality of nursing care documentation

\section{PENDAHULUAN}

Pelayanan keperawatan merupakan bagian dari pelayanan kesehatan yang berperan besar menentukan pelayanan kesehatan yang berkualitas. Keperawatan sebagai profesi dan perawat sebagai tenaga profesional dan bertanggung jawab untuk memberikan pelayanan keperawatan sesuai dengan kompetensi dan kewenangan yang dimiliki secara mandiri maupun bekerjasama dengan anggota kesehatan lainnya (Depkes RI, 2005). Pelayanan keperawatan diberikan dalam bentuk kinerja perawat yang harus didasari kemampuan yang tinggi sehingga mendukung pelaksanaan tugas perawat dalam pemberian asuhan keperawatan yang berkualitas.

Kualitas asuhan keperawatan dapat tergambar dari dokumentasi asuhan keperawatan. Dokumentasi asuhan keperawatan memegang peranan penting terhadap segala macam tuntutan masyarakat yang semakin kritis dan mempengaruhi kesadaran masyarakat akan hak-haknya dari suatu unit kesehatan (lyer, 2001).

Dokumentasi asuhan keperawatan merupakan bentuk pencatatan dan pelaporan yang dilakukan perawat dalam setiap pelaksanaan asuhan keperawatan pada pasien mulai dari pengkajian, merumuskan diagnosa, perencanaan, pelaksanaan dan evaluasi. Dokumentasi harus relevan, fokus pada klien, komprehensif, tepat waktu, fleksibel, mendapatkan data penting pasien, menjaga kualitas dan keberlangsungan perawatan, riwayat klien, tujuan dan menunjukkan standar tertentu. Ciri dokumentasi asuhan keperawatan yang baik adalah fakta (factual basis), akurat (accuracy), lengkap (completeness), ringkas ( conciseness), terorganisir (organization), waktu yang tepat (time liness) dan bersifat mudah dibaca (legability) (Potter \& Perry, 2005). 
Dokumentasi asuhan keperawatan yang tidak dilakukan dengan lengkap yang dapat menurunkan kualitas pelayanan keperawatan karena tidak dapat mengidentifikasi sejauh mana tingkat keberhasilan asuhan keperawatan yang diberikan, dalam aspek legal perawat tidak mempunyai bukti tertulis jika klien menuntut ketidakpuasan akan pelayanan keperawatan (lyer, 2001). Hal ini menjadi wujud dari kinerja perawat dalam melaksanakan asuhan keperawatan melalui pendokumentasikan asuhan keperawatan yang berkualitas.

Dari hasil evaluasi studi dokumentasi terhadap 20 rekam medis pasien, didapatkan hasil dokumentasi pengkajian keperawatan hanya $47 \%$, merumuskan diagnosa keperawatan $54 \%$, tindakan keperawatan $47 \%$, evaluasi $50 \%$ dan menulis catatan keperawatan $67 \%$. Dari hasil kuisioner 73,3 \% perawat mendokumentasikan hasil implementasi setiap selesai menjalankan tindakannya, namun masih sebatas tindakan medis dan tidak semua proses asuhan keperawatan dicatat di status pasien. Hal ini juga diperkuat oleh penelitian yang dilakukan oleh Sandra (2012) di RSUD Pariaman didapatkan bahwa pelaksanaan pendokumentasian asuhan keperawatan yang dilakukan oleh perawat pelaksana $60,5 \%$ buruk, dimana satiap aspek yang ada dalam format dokumentasi tidak seluruhnya di lengkapi dan cara pengisian format tidak sesuai dengan standar dokumentasi keperawatan yaitu 75\% (Depkes RI, 2005).

Berdasarkan latar belakang dan studi dokumentasi tersebut maka peneliti melihat fungsi manajerial kepala ruangan dan kinerja perawat dalam pelaksanaan dokumentasi asuhan keperawatan di ruang rawat inap RSUD Pariaman belum terlaksana dengan baik. Berdasarkan fenomena yang terjadi diatas, maka peneliti tertarik untuk meneliti tentang "Analisis Hubungan Fungsi Manajerial Kepala Ruangan dan Faktor-faktor Yang Mempengaruhi Kinerja perawat dengan Kualitas Dokumentasi Asuhan Keperawatan Di Ruang Inap RSUD Pariaman".

\section{METODE PENELITIAN}

Penelitian ini merupakan penelitian kuantitatif dengan jenis analitik deskriptif untuk menganalisis fungsi manajerial kepala ruangan, faktor-faktor yang berhubungan dengan kinerja perawat dan kualitas dokumentasi asuhan keperawatan. Variabel independen pada penelitian ini adalah fungsi manajerial kepala ruangan, faktor individu (umur, tingkat pendidikan, masa kerja, status kepegawaian), faktor organisasi (imbalan), faktor psikologis (sikap dan motivasi) dan variabel dependen adalah kualitas dokumentasi asuhan keperawatan. Pendekatan yang digunakan pada penelitian ini adalah cross sectional. Populasi dalam penelitian ini adalah seluruh perawat pelaksana yang berada di rawat Inap RSUD Pariaman sebanyak 110 orang. Teknik atau prosedur sampel yang digunakan untuk mengukur kinerja perawat adalah dilakukan dengan cara Proportional Random Sampling dengan jumlah sampel 86 orang perawat pelaksana dan studi dokumentasi pada rekam medis pasien

\section{HASIL DAN PEMBAHASAN Analisa Univariat Faktor individu}

Tabel 1. Distribusi rata-rata umur dan masa kerja perawat di ruang rawat Inap RSUD Pariaman $(n=86)$

\begin{tabular}{cccc}
\hline Variabel & Mean & $\begin{array}{c}\text { Minimal- } \\
\text { Maksimal }\end{array}$ & $\mathbf{9 5 \%} \mathbf{~ C l}$ \\
\hline Umur & 31,23 & $22-55$ & $29.84-32,62$ \\
Masa kerja & 5,98 & $1-30$ & $4.83-7,13$ \\
\hline
\end{tabular}

Berdasarkan tabel menunjukkan bahwa rata-rata umur perawat adalah 31,23 tahun dengan umur termuda 22 tahun dan umur tertua 55 tahun.. Rata-rata masa kerja perawat adalah rata-rata 5,98 tahun dengan masa kerja perawat minimal 1 tahun dan maksimal 30 tahun.

Tabel 2. Distribusi frekuensi responden berdasarkan Tingkat Pendidikan,Status Kepegawaian, imbalan, sikap dan motivasi Perawat di Ruang Rawat Inap RSUD Pariaman $(n=86)$

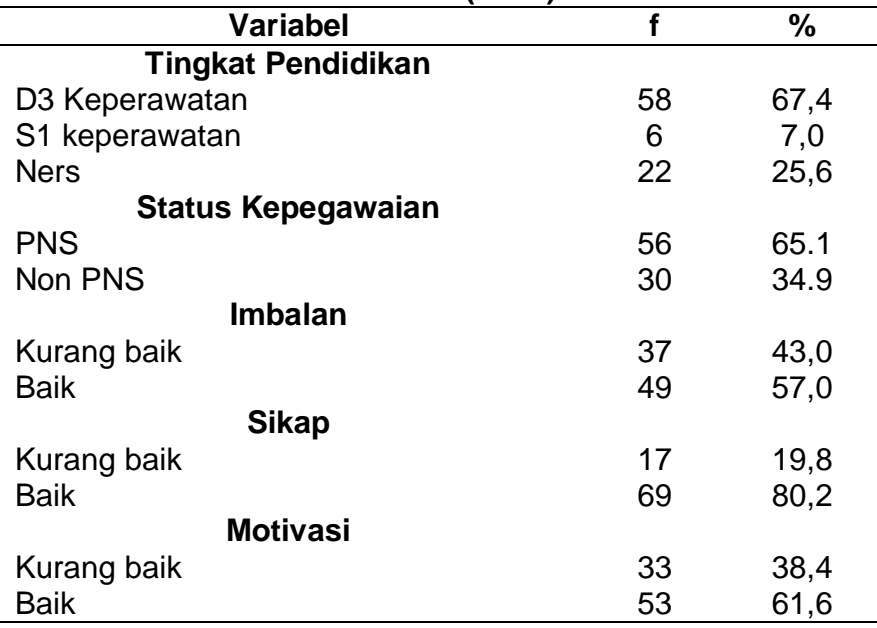

Berdasarkan tabel menunjukkan bahwa sebagian besar perawat berpendidikan D3 Keperawatan yaitu $67,4 \%$ dan status kepegawaian paling banyak adalah PNS yaitu $65,1 \%$. Sebagian besar imbalan dinyatakan baik yaitu $57,0 \%$. Sebagian besar sikap perawat baik yaitu $80,2 \%$ dan motivasi sebagian besar baik yaitu $61,6 \%$.

Tabel 3. Distribusi frekuensi responden berdasarkan fungsi manajerial kepala ruangandi Ruang Rawat Inap RSUD Pariaman $(n=86)$

\begin{tabular}{|c|c|c|}
\hline $\begin{array}{c}\text { Fungsi manajerial kepala } \\
\text { ruangan }\end{array}$ & f & $\%$ \\
\hline \multicolumn{3}{|l|}{ Fungsi perencanaan } \\
\hline Kurang baik & 23 & 26,7 \\
\hline Baik & 63 & 73,3 \\
\hline \multicolumn{3}{|l|}{ Fungsi Pengorganisasian } \\
\hline Kurang baik & 43 & 50,0 \\
\hline Baik & 43 & 50,0 \\
\hline \multicolumn{3}{|l|}{ Fungsi Pengarahan } \\
\hline Kurang baik & 12 & 14,0 \\
\hline Baik & 74 & 86,0 \\
\hline \multicolumn{3}{|l|}{ Fungsi Pengawasan } \\
\hline $\begin{array}{l}\text { Kurang baik } \\
\text { Baik }\end{array}$ & $\begin{array}{l}33 \\
53\end{array}$ & $\begin{array}{l}38,4 \\
61.6\end{array}$ \\
\hline \multicolumn{3}{|l|}{ Fungsi Pengendalian } \\
\hline $\begin{array}{l}\text { Kurang baik } \\
\text { Baik }\end{array}$ & $\begin{array}{l}39 \\
47\end{array}$ & $\begin{array}{l}45,3 \\
54,7\end{array}$ \\
\hline
\end{tabular}


Berdasarkan tabel diatas menunjukkan bahwa fungsi perencanaan paling banyak baik yaitu sebanyak $63(73,3 \%)$. Fungsi pengorganisasian baik yaitu 43 (50\%). Fungsi pengarahan yang baik yaitu $74(86,0 \%)$. Fungsi pengawasan baik yaitu $53(61,6 \%)$ dan fungsi pengendalian baik yaitu $47(54,7 \%)$.

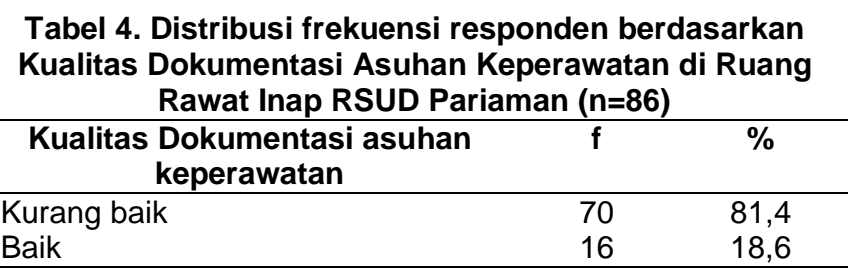

Berdasarkan tabel diatas menunjukkan bahwa sebagian besar kualitas dokumentasi asuhan keperawatan kurang baik yaitu $70(81,4 \%)$.

Tabel 5. Distribusi frekuensi Aspek penilaian Kualitas Dokumentasi Asuhan Keperawatan di Ruang Rawat Inap RSUD Pariaman $(n=86)$

\begin{tabular}{lcc}
\hline $\begin{array}{l}\text { Kualitas Dokumentasi asuhan } \\
\text { keperawatan }\end{array}$ & $\mathbf{f}$ & $\%$ \\
\hline $\begin{array}{l}\text { Pengkajian } \\
\text { Kurang baik } \\
\text { Baik Diagnosa keperawatan }\end{array}$ & 40 & 46,5 \\
$\quad \begin{array}{l}\text { Kurang baik } \\
\text { Baik Rencana keperawatan }\end{array}$ & - & 53,5 \\
$\quad$ Kurang baik & 76 & - \\
Baik Tindakan keperawatan & 14 & 83,7 \\
$\quad$ Kurang baik & 76,3 \\
Baik Evaluasi keperawatan & 10 & 88,4 \\
$\quad$ Kurang baik & & 11,6 \\
Baik $\quad$ Catatan asuhan keperawatan & 15 & 82,6 \\
Kurang baik \\
Baik
\end{tabular}

Berdasarkan tabel diatas menunjukkan bahwa pengkajian keperawatan 53,5\% baik, diagnosa keperawatan $100 \%$ baik, rencana keperawatan $84,7 \%$ kurang baik, tindakan keperawatan $88,4 \%$ kurang baik, evaluasi keperawatan $82,6 \%$ kurang baik dan catatan asuhan keperawatan $86 \%$ baik.

\section{Analisa bivariat}

Tabel 6. Hubungan umur dan masa kerja perawat dengan kualitas dokumentasi asuhan keperawatan di Ruang Rawat Inap RSUD Pariaman $(n=86)$

\begin{tabular}{cccc}
\hline Variabel & $\begin{array}{c}\text { Kualitas Dokumentasi } \\
\text { Asuhan Keperawatan }\end{array}$ & Mean & $\begin{array}{c}\boldsymbol{p} \\
\text { value }\end{array}$ \\
\hline Umur & Kurang baik & 43,76 & 0,841 \\
Masa & Baik & 42,38 & \\
kerja & Kurang baik & 44,27 & 0,547 \\
\hline & Baik & 40,12 & \\
\hline
\end{tabular}

Berdasarkan tabel diatas menunjukkan bahwa rata-rata umur perawat yang kualitas dokumentasi kurang baik yaitu 43,76 ,sedangkan rata-rata umur perawat yang kualitas dokumentasi asuhan keperawatan baik adalah 42,38 . Hasil uji statistik didapatkan $p$ value $0,841>0,05$, berarti terlihat tidak ada perbedaan yang signifikan rata-rata umur antara kualitas dokumentasi asuhan keperawatan yang kurang baik dan yang baik. Dan rata-rata masa kerja perawat yang kualitas dokumentasi asuhan keperawatan kurang baik yaitu 44,27 , sedangkan rata-rata masa kerja perawat yang kualitas dokumentasi asuhan keperawatan baik adalah 40,12 . Hasil uji statistik didapatkan $p$ value $0,547>0,05$, berarti juga tidak ada perbedaan yang signifikan ratarata masa kerja antara kualitas dokumentasi asuhan keperawatan yang kurang baik dan yang baik.

Tabel 7. Hubungan tingkat pendidikan dengan kualitas dokumentasi asuhan keperawatan di Ruang Rawat Inap RSUD Pariaman $(n=86)$

\begin{tabular}{cccccccc}
\hline & \multicolumn{4}{c}{ Kualitas Dokumentasi asuhan } & \\
Tingkat & \multicolumn{5}{c}{$\begin{array}{c}\boldsymbol{p} \\
\text { kendidikan }\end{array}$} & $\begin{array}{c}\text { Kurang } \\
\text { Baik }\end{array}$ & \multicolumn{2}{c}{ Baik } & Total & \\
value \\
\cline { 2 - 6 } & $\mathbf{f}$ & $\%$ & $\mathbf{f}$ & $\%$ & $\mathbf{f}$ & $\%$ & \\
\hline D3 Kep & 49 & 84,5 & 9 & 15,5 & 58 & 100 & \\
S.Kep & 5 & 83,3 & 1 & 16,7 & 6 & 100 & 0,479 \\
Ners & 16 & 72,7 & 6 & 27,3 & 22 & 100 & \\
\hline
\end{tabular}

Berdasarkan tabel diatas menunjukkan bahwa dari 58 responden tingkat pendidikan D3 Keperawatan dengan kualitas dokumentasi asuhan keperawatan yang kurang baik $84,5 \%$ dan baik $15,5 \%$, dari 6 responden yang tingkat pendidikan S.kep dengan kualitas dokumentasi asuhan keperawatan kurang baik $83,3 \%$ dan baik $16,7 \%$ dan dari 22 responden yang tingkat pendidikan Ners dengan kualitas dokumentasi asuhan keperawatan kurang baik $72,7 \%$ dan baik $27,3 \%$. Hasil uji statistik didapatkan bahwa $p$ value $0,479>0,05$ sehingga dapat dinyatakan tidak adanya hubungan yang signifikan antara tingkat pendidikan dengan kualitas dokumentasi asuhan keperawatan.

Tabel 8. Hubungan Status Kepegawaian dengan Kualitas Dokumentasi Asuhan Keperawatan di Ruang Rawat Inap RSUD Pariaman ( $n=86$ )

\begin{tabular}{|c|c|c|c|c|c|c|c|}
\hline \multirow{3}{*}{$\begin{array}{c}\text { Status } \\
\text { Kepegawaia } \\
\mathbf{n}\end{array}$} & \multicolumn{6}{|c|}{$\begin{array}{l}\text { Kualitas Dokumentasi asuhan } \\
\text { keperawatan }\end{array}$} & \multirow{3}{*}{$\begin{array}{c}p \\
\text { value }\end{array}$} \\
\hline & \multicolumn{2}{|c|}{$\begin{array}{c}\text { Kurang } \\
\text { Baik }\end{array}$} & \multicolumn{2}{|c|}{ Baik } & \multicolumn{2}{|c|}{ Total } & \\
\hline & $f$ & $\%$ & $f$ & $\%$ & $f$ & $\%$ & \\
\hline Non PNS & 22 & $\begin{array}{c}73 \\
3\end{array}$ & 8 & $\begin{array}{c}26 \\
7\end{array}$ & 30 & 100 & \\
\hline PNS & 48 & $\begin{array}{c}85 \\
7\end{array}$ & 8 & $\begin{array}{c}14 \\
3\end{array}$ & 56 & 100 & U, ८०5 \\
\hline
\end{tabular}

Berdasarkan tabel diatas menunjukkan bahwa dari 30 responden yang Non PNS dengan kualitas asuhan keperawatan kurang baik $73,3 \%$ dan baik $26,7 \%$. Sedangkan dari 56 responden yang PNS dengan kualitas dokumentasi asuhan keperawatan yang kurang baik $85,7 \%$ dan baik $14,3 \%$. Hasil uji statistik didapatkan bahwa tidak ada hubungan yang signifikan antara status kepegawaian dengan kualitas dokumentasi asuhan keperawatan ( $p$ value $=0,265$ ) 
Tabel 9. Hubungan antara imbalan dengan kualitas Dokumentasi Asuhan Keperawatan di Ruang Rawat Inap RSUD Pariaman ( $\mathrm{n}=86$ )

Kualitas Dokumentasi asuhan keperawatan

\begin{tabular}{|c|c|c|c|c|c|c|c|}
\hline \multirow{3}{*}{ Imbalan } & \multicolumn{6}{|c|}{ watan } & \multirow{3}{*}{$\begin{array}{c}p \\
\text { value }\end{array}$} \\
\hline & \multicolumn{2}{|c|}{$\begin{array}{c}\text { Kurang } \\
\text { Baik }\end{array}$} & \multicolumn{2}{|c|}{ Baik } & \multicolumn{2}{|c|}{ Total } & \\
\hline & $f$ & $\%$ & $f$ & $\%$ & $f$ & $\%$ & \\
\hline $\begin{array}{c}\text { Kurang } \\
\text { baik }\end{array}$ & 32 & 86,5 & 5 & 13,5 & 37 & 100,0 & 0,439 \\
\hline Baik & 38 & 77,6 & 11 & 22,4 & 49 & 100,0 & \\
\hline
\end{tabular}

Berdasarkan tabel diatas menunjukkan bahwa dari 37 responden yang imbalan kurang baik dengan kualitas dokumentasi asuhan keperawatan kurang baik $86,5 \%$ dan baik $13,5 \%$ dan imbalan yang baik dengan kualitas dokumentasi asuhan keperawatan kurang baik $77,6 \%$ dan baik $22,4 \%$. Hal ini menunjukkan bahwa imbalan perawat yang baik lebih besar memiliki kualitas dokumentasi asuhan keperawatan yang kurang baik. Hasil uji statistik didapatkan bahwa bahwa $p$ value $(0,439)>0,05$ yang berarti tidak ada hubungan yang signifikan antara imbalan dengan kualitas dokumentasi asuhan keperawatan.

Tabel 10. Hubungan sikap dengan kualitas dokumentasi asuhan keperawatan di Ruang Rawat Inap RSUD Pariaman $(\mathrm{n}=86)$

\begin{tabular}{|c|c|c|c|c|c|c|c|}
\hline \multirow{3}{*}{ Sikap } & \multicolumn{6}{|c|}{$\begin{array}{l}\text { Kualitas Dokumentasi asuhan } \\
\text { keperawatan }\end{array}$} & \multirow{3}{*}{$\begin{array}{c}P \\
\text { value }\end{array}$} \\
\hline & \multicolumn{2}{|c|}{$\begin{array}{l}\text { Kurang } \\
\text { Baik }\end{array}$} & \multicolumn{2}{|c|}{ Baik } & \multicolumn{2}{|c|}{ Total } & \\
\hline & $f$ & $\%$ & $f$ & $\%$ & $f$ & $\%$ & \\
\hline Kurang & 14 & 82,4 & 3 & 17,6 & 17 & 100 & \\
\hline $\begin{array}{l}\text { Baik } \\
\text { Baik }\end{array}$ & 56 & 81,2 & 13 & 18,8 & 69 & 100 & 1,000 \\
\hline
\end{tabular}

Berdasarkan tabel diatas menunjukkan bahwa dari 17 responden yang sikap perawat kurang baik dengan kualitas dokumentasi asuhan keperawatan kurang baik $82,4 \%$ dan baik $17,6 \%$. Sedangkan dari 69 responden yang sikap perawat baik dengan kualitas dokumentasi asuhan keperawatan kurang 81,2\% dan baik $18,8 \%$. Hal ini menunjukkan bahwa sikap perawat yang baik lebih besar memiliki kualitas dokumentasi asuhan keperawatan yang kurang baik. Hasil uji statistik didapatkan bahwa $p$ value $(1,000)>0,05$ yang berarti tidak ada hubungan yang signifikan antara sikap dengan kualitas dokumentasi asuhan keperawatan.

Tabel 11. Hubungan Motivasi dengan Kualitas Dokumentasi Asuhan Keperawatan di Ruang Rawat Inap RSUD Pariaman $(n=86)$

\begin{tabular}{|c|c|c|c|c|c|c|c|}
\hline \multirow{3}{*}{ Motivasi } & \multicolumn{6}{|c|}{$\begin{array}{c}\text { Kualitas Dokumentasi asuhan } \\
\text { keperawatan }\end{array}$} & \multirow{3}{*}{$\begin{array}{c}p \\
\text { value }\end{array}$} \\
\hline & \multicolumn{2}{|c|}{ Kurang Baik } & \multicolumn{2}{|c|}{ Baik } & \multicolumn{2}{|c|}{ Total } & \\
\hline & $f$ & $\%$ & $\mathbf{F}$ & $\%$ & $f$ & $\%$ & \\
\hline Kurang & 2 & 81,8 & 6 & 18, & 3 & 100 & \\
\hline Baik & 7 & & & 2 & 3 & & 1000 \\
\hline Baik & $\begin{array}{l}4 \\
3\end{array}$ & 81,1 & $\begin{array}{l}1 \\
0\end{array}$ & $\begin{array}{c}18 \\
9\end{array}$ & $\begin{array}{l}5 \\
3\end{array}$ & 100 & 1,000 \\
\hline
\end{tabular}

Berdasarkan tabel diatas menunjukkan bahwa dari 33 responden yang motivasi kurang baik dengan kualitas dokumentasi asuhan keperawatan kurang baik
$81,8 \%$ dan baik $18,2 \%$. Sedangkan dari 53 responden yang motivasi baik dengan kualitas dokumentasi asuhan keperawatan kurang baik $81,1 \%$ dan baik $18,9 \%$. Hal ini menunjukkan bahwa perawat dengan motivasi yang baik memiliki sebagian besar kualitas dokumentasi asuhan keperawatan yang kurang baik. Hasil uji statistik didapatkan bahwa bahwa $p$ value $(1,000)>0,05$ yang berarti tidak ada hubungan yang signifikan antara motivasi dengan kualitas dokumentasi asuhan keperawatan.

Tabel 12. Hubungan Fungsi Manajerial Kepala Ruangan dengan Kualitas Dokumentasi Asuhan Keperawatan di Ruang Rawat Inap RSUD Pariaman tahun 2016 ( $n=86)$

\begin{tabular}{|c|c|c|c|c|c|c|c|}
\hline \multirow{3}{*}{$\begin{array}{c}\text { Fungsi } \\
\text { Manajerial } \\
\text { Kepala } \\
\text { Ruangan }\end{array}$} & \multicolumn{6}{|c|}{$\begin{array}{c}\text { Kualitas Dokumentasi asuhan } \\
\text { keperawatan }\end{array}$} & \multirow{3}{*}{$\begin{array}{c}p \\
\text { value }\end{array}$} \\
\hline & \multicolumn{2}{|c|}{$\begin{array}{l}\text { Kurang } \\
\text { Baik }\end{array}$} & \multicolumn{2}{|c|}{ Baik } & \multicolumn{2}{|c|}{ Total } & \\
\hline & $f$ & $\%$ & $f$ & $\%$ & $f$ & $\%$ & \\
\hline \multicolumn{8}{|l|}{$\begin{array}{c}\text { Fungsi } \\
\text { Perencanaan }\end{array}$} \\
\hline Kurang Baik & 18 & 78,3 & 5 & 21,7 & 23 & 100 & \multirow{2}{*}{0,756} \\
\hline Baik & 52 & 82,5 & 11 & 17,5 & 63 & 100 & \\
\hline \multicolumn{8}{|l|}{$\begin{array}{c}\text { Fungsi } \\
\text { Pengorganisa } \\
\text { sian }\end{array}$} \\
\hline Kurang Baik & 33 & 76,7 & 10 & 23,3 & 43 & 100 & \multirow{2}{*}{0,406} \\
\hline Baik & 37 & 86,0 & 6 & 14,0 & 43 & 100 & \\
\hline \multicolumn{8}{|l|}{$\begin{array}{c}\text { Fungsi } \\
\text { Pengarahan }\end{array}$} \\
\hline Kurang Baik & 7 & 58,3 & 5 & 41,7 & 12 & 100 & \multirow{2}{*}{0,042} \\
\hline Baik & 63 & 85,1 & 11 & 14,9 & 74 & 100 & \\
\hline \multirow{2}{*}{\multicolumn{8}{|c|}{$\begin{array}{c}\text { Fungsi } \\
\text { Pengawasan }\end{array}$}} \\
\hline & & & & & & & \\
\hline Kurang Baik & 25 & 75,8 & 8 & 24,2 & 33 & 100 & \multirow{3}{*}{0,438} \\
\hline Baik & 45 & 84,9 & 8 & 15,1 & 53 & 100 & \\
\hline \multirow{2}{*}{\multicolumn{8}{|c|}{$\begin{array}{c}\text { Fungsi } \\
\text { Pengendalian }\end{array}$}} \\
\hline & & & & & & & \\
\hline Kurang Baik & 32 & 82,1 & 7 & 17,9 & 39 & 100 & \multirow{2}{*}{1,000} \\
\hline Baik & 38 & 80,9 & 9 & 19,1 & 47 & 100 & \\
\hline
\end{tabular}

Berdasarkan tabel menunjukkan bahwa dari 23 responden yang fungsi perencanaan kurang baik $78,3 \%$ dan baik $21,7 \%$, sedangkan dari 63 responden dengan fungsi perencanaan yang baik dengan kualitas dokumentasi asuhan keperawatan kurang baik $82,5 \%$ dan baik $17,5 \%$. Hasil uji statistik didapatkan bahwa $p$ value $(0,756)>0,05$ yang berarti tidak ada hubungan yang signifikan antara fungsi perencanaan dengan kualitas dokumentasi asuhan keperawatan.

Hasil analisis dari 43 responden yang fungsi pengorganisasian yang kurang baik dengan kualitas dokumentasi asuhan keperawatan yang kurang baik $76,7 \%$ dan baik yaitu $23,3 \%$ dan dari 43 responden yang fungsi pengorganisasian yang baik dengan kualitas dokumentasi asuhan keperawatan kurang baik 86,0\% dan baik $14,0 \%$. Hasil uji statistik didapatkan bahwa $p$ value $0,406>0,05$ artinya tidak ada hubungan yang signifikan antara fungsi pengorganisasian dengan kualitas dokumentasi asuhan keperawatan.

Hasil analisis dari 12 responden yang fungsi pengarahan kurang baik dengan kualitas dokumentasi asuhan keperawatan yang kurang baik 58,3 dan baik $41,7 \%$ sedangkan dari 74 responden yang fungsi pengarahan baik dengan kualitas dokumentasi asuhan 
keperawatan kurang baik $85,1 \%$ dan baik $14,9 \%$. Hasil uji statistik didapatkan bahwa $p$ value $(0,042)<0,05$ yang berarti ada hubungan yang signifikan antara fungsi pengarahan dengan kualitas dokumentasi asuhan keperawatan. Nilai OR 0,244 (Cl 95\%: 0,066-0,910) yang diartikan bahwa fungsi pengarahan yang baik memiliki peluang 0,244 kali untuk kualitas dokumentasi asuhan keperawatan yang baik dibandingkan yang kurang baik.

Hasil analisis dari 33 responden yang fungsi pengawasan kurang baik $75,8 \%$ dan baik $24,2 \%$ sedangkan 53 responden yang fungsi pengawasan baik dengan kualitas dokumentasi asuhan keperawatan yang kurang baik $84,9 \%$ dan baik $15,1 \%$. Hasil uji statistik didapatkan bahwa $p$ value $(0,438)>0,05$ yang berarti tidak ada hubungan yang signifikan antara fungsi pengawasan dengan kualitas dokumentasi asuhan keperawatan.

Hasil analisis dari 39 responden yang fungsi pengendalian kurang baik dengan kualitas dokumentasi asuhan keperawatan yang kurang baik $82,1 \%$ dan baik $17,9 \%$ sedangkan dari 47 responden yang fungsi pengendalian baik dengan kualitas dokumentasi asuhan keperawatan yang kurang baik $80,9 \%$ dan baik $19,1 \%$. Hasil uji statistik didapatkan bahwa $p$ value $(1,000)>$ 0,05 yang berarti tidak ada hubungan yang signifikan antara fungsi pengendalian dengan kualitas dokumentasi asuhan keperawatan.

\section{Analisa Multivariat}

Tabel 13. Hasil Seleksi Bivariat fungsi manajerial , faktorfaktor kinerja dengan kualitas dokumentasi asuhan keperawatan di ruang rawat inap RSUD Pariaman

\begin{tabular}{lc}
\multicolumn{1}{c}{ Variabel } & p value \\
\hline Fungsi Perencanaan & 0,652 \\
Fungsi Pengorganisasian & 0,272 \\
Fungsi Pengarahan & 0,036 \\
Fungsi Pengawasan & 0,293 \\
Fungsi Pengendalian & 0,887 \\
Umur & 1,000 \\
Masa kerja & 0,580 \\
Tingkat pendidikan & 0,243 \\
Status kepegawaian & 0,165 \\
Imbalan & 0,296 \\
Sikap & 0,910 \\
Motivasi & 0,937 \\
\hline
\end{tabular}

Berdasarkan tabel diatas variabel yang dapat dimasukkan dalam pemodelan ada 3 yaitu fungsi pengarahan dengan $p$ value 0,036 , tingkat pendidikan dengan $p$ value 0,243 dan status kepegawaian dengan $p$ value 0,165 dimana $p$ value $<0,25$.

Tabel 14. Analisis Pemodelan Multivariat Regresi Logistik Ganda Variabel Fungsi Pengarahan Kepala Ruangan, Tingkat Pendidikan, Status kepegawaian dengan Kualitas Dokumentasi Asuhan Keperawatan Diruang Rawat Inap RSUD Pariaman

\begin{tabular}{|c|c|c|c|c|}
\hline Variabel & B & $P$ value & $\operatorname{Exp}(B)$ & $\mathrm{Cl} 95 \%$ \\
\hline Tahap 1 & & & & \\
\hline Pendidikan & 0,482 & 0,143 & 1,618 & $0,581-3,076$ \\
\hline Fungsi Pengarahan & $-1,789$ & 0,016 & 0,167 & $0,039-0,714$ \\
\hline $\begin{array}{c}\text { Status kepegawaian } \\
\text { Tahap } 2\end{array}$ & 1,312 & 0,043 & 3,712 & $1,041-13,237$ \\
\hline Fungsi Pengarahan & $-1,748$ & 0,017 & 0,174 & $0,042-0,728$ \\
\hline $\begin{array}{c}\text { Status kepegawaian } \\
\text { Tahap } 3\end{array}$ & 1,121 & 0,071 & 3,067 & $0,907-10,365$ \\
\hline Fungsi Pengarahan & $-1,748$ & 0,017 & 0,174 & $0,042-0,728$ \\
\hline
\end{tabular}

Berdasarkan tabel diatas nilai $p$ yang $<0,05$ yaitu fungsi pengarahan $(p$ value $=0,017)$ yang artinya dari 3 variabel yang masuk dalam pemodelan, yang berpengaruh terhadap kualitas dokumentasi asuhan keperawatan adalah fungsi pengarahan. Nilai OR fungsi pengarahan kepala ruangan yaitu 0,174 artinya bahwa fungsi pengarahan kepala ruangan yang baik berpeluang 0,174 kali (Cl95\%: 0,012-0,728) untuk meningkatkan kualitas dokumentasi asuhan keperawatan yang baik dibandingkan yang kurang baik.

\section{SIMPULAN}

Simpulan dari penelitian ini berdasarkan tujuan dan hasil penelitian sebagai berikut:

a. Fungsi manajerial kepala ruangan yang terdiri dari fungsi perencanaan kepala ruangan sebagian besar baik, fungsi pengorganisaian sama besar antara yang baik dan kurang baik, fungsi pengarahan sebagian besar baik, fungsi pengawasan sebagian besar baik dan fungsi pengendalian sebagian besar baik.

b. Faktor individu yang terdiri dari umur perawat ratarata 31,2 tahun dengan umur termuda 22 tahun dan tertua 55 tahun, masa kerja rata-rata 5,9 tahun dengan masa kerja terbaru 1 tahun dan terlama 30 tahun, status kepegawaian sebagian besar adalah PNS, dan tingkat pendidikan perawat sebagian besar adalah D3 Keperawatan.

c. Faktor organisasi yaitu imbalan sebagian besar adalah baik.

d. Faktor psikologis yang terdiri dari sikap dan motivasi sebagian besar adalah baik.

e. Kualitas dokumentasi asuhan keperawatan sebagian besar adalah kurang baik

f. Tidak adanya hubungan antara faktor individu (umur, masa kerja, status kepegawaian dan tingkat pendidikan) dengan kualitas dokumentasi asuhan keperawatan.

g. Tidak adanya hubungan antara faktor organisasi (imbalan) dengan kualitas dokumentasi asuhan keperawatan.

h. Tidak adanya hubungan antara faktor psikologis (sikap dan motivasi) dengan kualitas dokumentasi asuhan keperawatan.

i. Tidak adanya hubungan antara fungsi perencanaan dengan kualitas dokumentasi asuhan keperawatan. 
j. Tidak adanya hubungan antara fungsi pengorganisasian dengan kualitas dokumentasi asuhan keperawatan.

k. Adanya hubungan antara fungsi pengarahan dengan kualitas dokumentasi asuhan keperawatan.

I. Tidak adanya hubungan antara fungsi pengawasan dengan kualitas dokumentasi asuhan keperawatan.

m. Tidak adanya hubungan antara fungsi pengendalian dengan kualitas dokumentasi asuhan keperawatan.

n. Fungsi pengarahan yang paling berhubungan dengan kualitas dokumentasi asuhan keperawatan.

\section{Saran}

Berdasarkan kesimpulan diatas, peneliti mengusulkan kepada:

\section{Bidang keperawatan RSUD Pariaman}

Melakukan revisi Standar asuhan keperawatan sesuai dengan kondisi dan pedoman saat ini, Melakukan penilaian kinerja perawat tentang pendokumentasian asuhan keperawatan secara berkala dengan menggunakan instrumen penilaian sesuai kebutuhan rumah sakit dan disepakati bersama, Penyelenggarakan pelatihan-pelatihan terkait dengan dokumentasi asuhan keperawatan yang sesuai standar yang dibina oleh tenaga ahli dan professional

\section{Kepala Ruangan}

Meningkatkan kembali pengetahuannya tentang fungsi manajerial di raung rawat inap melalui seminar, pelatihan-pelatihan dan studi banding ke rumah sakit lain., Melibatkan perawat dalam setiap kegiatan asuhan keperawatan diruang rawat inap., Meningkatkan kinerja perawat pelaksana dalam mendokumentasikan asuhan keperawatan dengan mengadakan pelatihan-pelatihan tentang dokumentasi asuhan keperawatan yang berkualitas atau sesuai standar, melibatkan perawat dalam pembahasan kasus-kasus dan masalah yang ditemui selama bertugas.

\section{Perawat pelaksana}

Meningkatkan kinerja diri dengan mengikuti pelatihan-pelatihan tentang dokumentasi asuhan keperawatan yang berkualitas/ sesuai standar, memperbanyak membaca tentang kasus-kasus asuhan keperawatan dan standar diangnosa keperawatan yang digunakan oleh rumah sakit, Melibatkan diri dan berperan aktif dalam kegiatan yang dapat meningkatkan kualitas dokumentasi asuhan keperawatan.

\section{DAFTAR PUSTAKA}

Abd, S., Rashed, E., Mohamed, P., Mohamed, A., \& Torky, A. (2015). Performance of head nurses management functions and its effect on nurses ' productivity at Assiut University Hospital, 4(5), 3849.

Al-jebory, M. K., \& College, M. S. N. (n.d.). (2015). Evaluation of Nurse Manager Performance of Planning in Middle Euphrates Governorates Hospitals . Dr. Mohammed F . Khalifa , PhD . in Community Health Nursing Department, College of Nursing / University of Baghdad AIM OF THE STUDY: To evaluate the nurse manager performance of planning in middle Euphrates, 5(1).

Aditama. (2006). Manajemen Adminstrasi Rumah Sakit. Edisi 2. Jakarta. IU Press

Arwani dan Supriyanto. (2006). Manajemen Bangsal Keperawatan. EGC. Jakarta

Departemen Kesehatan Republik Indonesia. (2001). Instrumen Evaluasi Penerapan Standar Asuhan Keperawatan Di Rumah Sakit. Cetakan Keempat. Jakarta : Depkes RI

Departemen Kesehatan Republik Indonesia. (2005). Instrumen Evaluasi Penerapan Standar Asuhan Keperawatan Di Rumah Sakit. Jakarta : Depkes $\mathrm{RI}$

Ferdiansyah. (2006) Pengaruh beberapa faktor lingkungan kerja terhadap kinerja perawat bagian penyakit Dalam RSUD DR. Soetomo Surabaya. http://adln.lib.ac.id/go.

Gillies DA. (1994). Nursing Management : A System Approach. 3rd edition. Philadelphia : WB Saunders Company.

Hasibuan. (2005). Manajemen Sumber Daya Manusia. Edisi Revisi .Jakarta. PT Bumi Aksara

Hidayat. ( 2002). Dokumentasi Proses Keperawatan. Jakarta. EGC

Hagos, Fisseha et al. (2014). Application of Nursing Process and Its Affecting Factors among Nurses Working in Mekelle Zone Hospitals, Northern Ethiopia

Huber D. (2000). Leadership Nursing and Care Management. Second edition. Philadelphia : W.B. Saunders Company

Herdiana \& Rosa. (2011). Pengaruh Fungsi Manajerial Supervisi Klinik Terhadap Dokumentasi Asuhan Keperawatan Di RS Pku Muhammadiyah Yogyakarta. Bagian Magister Manajemen Rumah Sakit Universitas Muhammadiyah Yogyakarta

Ilyas Y. (2000). Perencanaan Sumber Daya Manusia Rumah Sakit ; Teori, Metode dan Formula. Edisi I. Jakarta : Pusat Kajian Ekonomi Kesehatan FKM UI.

Ilyas .Y. (2002). Kinerja, Teori, Penilaian dan penelitian. Pusat Kajian Ekonomi Kesehatan. FKM UI. Jakarta

lyer, PW\& Camp, NH. (2005). Dokumentasi Keperawatan: Suatu Pendekatan Proses Keprawatan. EGC. Jakarta

Keliat BK. (2000). Manajemen Asuhan Keperawatan. Jakarta : Tidak dipublikasikan.

Kontoro, A. ( 2010). Buku Ajar Manajemen Keperawatan. Mutiara Medika. 2010

Kumajas, dkk. (2013). Hubungan fungsi manajemen kepala ruangan dengan kinerja perawat di Badan Layanan Umum Rumah Sakit. Fakultas Kedokteran Universitas Hasanuddin Manado.

Maria, A., Ofei, A., Emmanuel, P., Sayi, K., Buabeng, T., \& Asiedua, E. (2014). Nurses perception of planning practices of nurse managers in the Greater Accra region, Ghana, 3(September), 3345.

Mangkunegara .(2005). Perilaku dan budaya organisasi. Bandung. Refieka Aditama 
Marquis BL, Huston CJ. (2000). The Leadership Rules and Management Functions in Nursing : Theory and Application. 3rd edition. Philadelphia : Lippincolt

Notoatmojo S. (2002). Metodologi Penelitian Kesehatan. Edisi Revisi. Jakarta : Rineka Cipta.

Nursalam. (2001). Proses dan dokumentasi keperawatan: konsep dan praktik, edisi pertama. Jakarta. Salemba Medika

Nursalam .(2008). Proses dan dokumentasi keperawatan : konsep dan praktik. Jakarta. Salemba Medika

Nursalam.(2012). Manajemen Keperawatan: Aplikasi dalam Praktik Keperawatan Profesional. Edisi pertama. Jakarta : Salemba Medika

Parmin. (2009). Hubungan pelaksanaan fungsi manajemen kepala ruangan dengan motivasi perawat pelaksana di ruang rawat inap RSUP Undata Palu. Tesis. Depok. FIK UI

Pandawa, Rugaya M. (2006). Determinan kinerja perawat pelaksana dalam pendokumentasian asuhan keperawatan di ruang rawat inap RSUD DR. H. Chasan Boiserie Ternate. Tesis. FIK UI

Perry \& Potter. (2005). Fundamental of Nursing . Jakarta. Salemba Medika

PPNI. (2005). Standar Kompetensi Perawat Indonesia. http://www.inna-ppni.or.id

PPNI. (2001). Standar Praktek Keperawatan. Draf.

Pribadi, A. (2009). Analisis pengaruh faktor pengetahuan, motivasi, dan persepsi perawat tentang supervisi kepala ruangan terhadap pelaksanaan dokumentasi asuhan keperawatan di ruang rawat inap RSUD Kelet Provinsi jawa Tengah Jepara. Tesis. Fakultas Kesehatan Masyarakat UNDIP Semarang.

Profil Rumah Sakit Umum Daerah Pariaman. (2015)

Ratnasih. (2001). Hubungan antara kemampuan kepala ruangan dalam melaksanakan fungsi manajemen dengan kinerja perawat pelaksana di ruang rawat inap RS Kepolisian Pusat Raden Said Sukanto Jakarta. Tesis. Tidak dipublikasikan. Jakarta. PPS FIK UI

Robbins. ( 2006). Perilaku Organisasi. Edisi 10. PT Indeks Kelompok. Garmedia

Royani. (2010). Hubungan sistem penghargaan dengan kinerja perawat dalam melaksanakan asuhan keperawatan di RSUD Cilegon Banten. Program Pascasarjana (Tesis tidak dipublikasikan).

Saleh. (2012). Pengaruh ronde terhadap tingkat kepuasan kerja perawat pelaksana diruang rawat inap RSUD Abdul Wahab Sjakranie Samarinda. Karya IImiah IImu Keperawatan

Sastroasmoro S, Ismael S. (2002). Dasar-dasar Metodologi Penelitian Klinis. Edisi ke 2. Jakarta : Sagung seto

Sandra, R. (2012). Analisis hubungan motivasi perawat pelaksana dengan pelaksanaan pendokumentasian asuhan keperawatan di ruang rawat inap RSUD Pariaman

Siagian. (2007). Fungsi-fungsi manajerial. Edisi revisi. Jakarta. PT Rineka Cipta

Simamora, Roymond.H. (2012). Buku Ajar Manajemen Keperawatan. Jakarta. EGC
Sri Wedati. Pengantar Manajemen Keperawatan. MMR UGM. Yogyakarta. 2003

Sumiyati, A. (2006). Analisis faktor-faktor yang berhubungan dengan Kinerja kepala ruang rawat inap di Rumah Sakit Dokter Kariadi Semarang Tahun 2006. Tesis. UNDIP

Sullivan EJ, Decker PJ. (1997). Effective Leadership and Management in Nursing. 4 th Edition. California : Addison-Wesley

Suarli \& Bahtiar. (2008). Manajemen keperawatan dengan pendekatan praktis. Jakarta. Erlangga

Soeprijadi. (2006). Faktor-faktor yang mempengaruhi dokumentasi asuhan keperawatan yang dilakukan oleh perawat di RS Grhasia Provinsi DIY. PSIK. FK

Sugiyono.(2012). Metode Penelitian Kuantitatif, Kualitatif, Dan R\&D , Bandung: Alfabeta

Swansburg RC, Swansburg RJ. (1999). Introductory Management and Leadership for

Nurse. 2nd edition. Toronto : Jonash and Burtlet Publisher

Syaifudin, dkk. (2013). Efektifitas perencanaan harian terhadap kinerja harian kepala ruang di ruang rawat inap RS Tugu lbu Depok. Prosiding Konferensi Nasional PPNI Jawa Tengah

Warsito.B.E. (2007). Jurnal Pengaruh Persepsi Perawat Pelaksana tentang Fungsi Manajerial kepala ruangan terhadap pelaksanaan manajemen asuhan keperawatan di ruang rawat inap RSJD Dr. Amino Gondohutomo Semarang. Volume 1. No. 1 tahun 2007.FKM UNDIP

Yanti \& Warsito. (2013). Jurnal manajemen keperawatan : hubungan karakteristik perawat, motivasi dan supervisi dengan kualitas dokumentasi asuhan keperawatan. vol 1 no.2 November 2013. Jurusan Keperawatan Fakultas Kedokteran Universitas Dipnegoro. 